\title{
Drawing on the Discursive Resources from Psychological Contracts to Construct Imaginary Selves: A Psychoanalytic Perspective on how Identity Work Drives Psychological Contracts
}

\section{By Michaela Driver, Ph.D.}

Chair in Management

University of Leicester

School of Business

Leicester, LE1 7RH

UK

Email:md308@1eicester.ac.uk

\section{Biographical Note:}

Michaela researches alternative and psychoanalytic approaches to a wide range of organizational topics such as motivation, stress, organizational identity and learning, emotions, trust, corporate social responsibility, identity work, creativity, embodied subjectivity, change and leadership. Journals in which Michaela's work has been published include Organization Studies, Human Relations, Academy of Management Learning \& Education, Organization, Management Learning, Journal of Organizational Change Management, Journal of Business Ethics, and Journal of Management Inquiry. She serves on several editorial boards including Human Relations, Organization Studies, Organization, Management Learning, and the Journal of Management Inquiry. 


\title{
Drawing on the Discursive Resources from Psychological Contracts to Construct Imaginary Selves: A Psychoanalytic Perspective on how Identity Work Drives Psychological Contracts
}

\author{
Abstract \\ The study contributes novel theoretical perspectives for a more comprehensive and processual \\ understanding of psychological contracts in the context of identity work. It builds on a \\ psychoanalytic, specifically Lacanian, perspective to analyze 106 psychological contract \\ narratives by employees of a wide range of organizations. Based on this analysis, the study \\ suggests that psychological contracts can be understood as providing discursive resources on \\ which narrators draw in complex and non-linear fashion to construct imaginary selves. Their \\ inevitable unsettlement prompts both imaginary and symbolic responses that seem independent \\ of the viability and type of psychological contract narrated. This suggests that identity work \\ drives psychological contracts in surprising ways and empowers individuals as contract and \\ identity-makers. Implications for psychological contract research are discussed.
}

Key Words: Psychological Contract, Identity, Discourse, Narratives, Psychoanalysis, Lacan

\section{Introduction}

The psychological contract is a mental model (Chaudhry and Song, 2014: 341) or schema (Rousseau, 2003: 233) containing “an employee's subjective understanding of promissory-based reciprocal exchanges between him or herself and the organization" (Conway and Briner, 2009: 35). It has been praised as "one of the best conceptual vehicles" (O’Leary-Kelly, Henderson, Anand and Ashforth, 2014: 327) for understanding what is at the heart of the employee-employer relationship. The psychological contract originally had roots in psychoanalysis with an emphasis on how unconscious needs affect this relationship (Meckler, Drake and Levinson, 2003). 
Research has since moved away from this perspective, which has been lamented as a significant oversight (Meckler et al., 2003), as unconscious aspects have always been part of understanding the psychological contract (Rousseau, 2003: 232).

The purpose of the present study is to revitalize such a perspective and follow the call for investigating the psychological contract relative to how individuals construct identities (Conway and Briner, 2009: 144). While there have been tentative steps in this direction linking psychological contracts to employees' self-concepts (e.g. Low, Bordia and Bordia, 2016: 1459), more complex theorizing is needed to explore them in the context of "the management of identity work [which has] become more salient and critical to the employment relationship" (Alvesson and Willmott, 2002:623). The present study accomplishes this by adopting a psychoanalytic, specifically Lacanian, perspective, which has been advanced as highly significant for understanding the complexities of identity work in organizations (Driver, 2009). It is employed here to investigate 106 stories in which individuals from a range of organizations describe their psychological contracts. The analysis elucidates how psychological contracts furnish discursive resources for the doing of identity work (Alvesson, Ashcraft and Thomas, 2008: 9), as the ongoing process by which discourses are drawn on to narrate the self (Clarke, Brown and Hailey, 2009: 326), and how this may be understood in light of struggles with unconscious desire and underlying lack (Lacan, 1988b).

In so doing, the study seeks to make a number of contributions to the field of psychological contract research. First, it offers a more fine-grained and nuanced understanding of how psychological contracts are related to identity. By reviving a psychoanalytic approach and introducing a Lacanian framework, the study suggests that identity work may be driving psychological contracts to a much greater extent than previously thought. It advances the idea 
that they are drawn on as discursive resources for the narrative construction of identities as an ongoing process of producing and reproducing selves, driven by the impossibility of fulfilling underlying, unconscious desire (Lacan, 1988b: 211). This, in turn, not only offers avenues for complex theorizing on the psychological contract but also for a more processual understanding of how psychological contracts work (Conway and Briner, 2009: 131).

Additionally, it offers new perspectives on how psychological contracts function in the context of organizational power and resistance. Research in the field has been criticized for ascribing a rather passive role to employees as contract-takers rather than makers (Lam and de Campos, 2015: 814; O'Leary-Kelly et al., 2014: 351), and for having a managerialist bias focusing frequently on how psychological contracts can be managed to benefit the employer (Conway and Briner, 2009: 174). The study addresses such criticisms and answers calls for research on how psychological contracts empower employees (Lam and de Campos, 2015: 812). It does so by advancing the idea that discursive resources from psychological contracts are used to do empowering work for subjects, with individuals being much more contract and identitymakers than previously assumed.

Following the call for more varied research methods (Conway and Briner, 2009: 183), the study also departs from common quantitative approaches (Conway and Briner, 2009: 98). In deploying storytelling methodology and qualitative narrative analysis, it offers research methods that more effectively accommodate the highly subjective nature of psychological contracts (O'Leary-Kelly et al., 2014: 328). In so doing, the study provides novel directions for how to study psychological contracts moving away from well-rehearsed dichotomies, such as intact versus broken, and transactional versus relational psychological contracts, toward exploring how 
they unfold over time at the interstice of complex human motivations and ongoing identity work (Meckler et al., 2003: 224).

\section{Psychological Contracts and Identity Work}

The most common definition of the psychological contract (Rousseau, 1995) centers on employee beliefs regarding the terms of an informal exchange agreement between themselves and their organization (Turnley and Feldman, 1999). This definition captures what individuals consciously believe about their work and organization, and the kinds of behaviors that will be rewarded by their employers, and emphasizes the social and economic aspects of the psychological contract (Meckler et al., 2003: 218). What it captures less well are more complex human motivations crucial for understanding what is at the core of psychological contracts, namely unconscious needs driving behavior while remaining outside of conscious perceptions (Meckler et al., 2003: 222). This fails to account for how psychological contracts unfold over time in the context of personal development and identity work (Meckler et al., 2003: 224).

The resulting gap surfaces in current research that "has progressed at an impressive rate" (O’Leary-Kelly et al., 2014: 327) but seems to be over-simplistic and linear while losing its capacity to account for the complexities of human behavior (Meckler et al., 2003: 219). This is even more acute in times of change, intensification of work, and the erosion of protections of the employment relationship (Coyle-Shapiro and Kessler, 2000: 904). While some studies have focused on how the psychological contract functions in light of "cost-cutting, downsizing, outsourcing and ethical scandals" (Phillipp and Lopez, 2013: 304), increasing uncertainty (Chaudhry and Song, 2014: 338) and employee experiences of "anxiety, fear and doubt" (Phillipp and Lopez, 2013: 304), how all of this unfolds in the context of identity work, and especially its unconscious dynamics, remains underexplored. 
The emphasis has been on studying breaches of psychological contracts as a common and nearly inevitable dynamic (Restubog, et al., 2015: 1133) leading to an increasing interest in the study of psychological contract violations, as the affective reactions to such breaches including strong emotions, like anger and a desire for revenge (Restubog et al., 2015: 1133). These have been linked to mistrust, lower commitment, poor performance, absenteeism and turnover (Lam and de Campos, 2015: 813). Increasingly research focuses on what happens when employee expectations around such working conditions as rewards, safety, job security, and fairness (Conway and Briner, 2009: 163) are not being met, signaling "to employees that they are not positively valued by the organization" (Coyle-Shapiro and Kessler, 2000: 923).

Yet beyond the insight that this involves "symbolic messages about the relationship between the organization and the employee" (Restubog, Hornsey, Bordia and Esposo, 2008: 1377), and negative impacts on organizational identification, by making the latter a less meaningful part of an employee's self-concept (Zagenczyk, Gibney, Few and Scott, 2011: 276), individual identity work has only been hinted at. For example, it has been found that psychological contract fulfillment, or lack thereof, is a reflection of how much the organization values their members' contributions and well-being (Kiewitz, Restubog, Zagenczyk and Hochwarter, 2009: 810), and that reactions to breaches are related to employees' evaluations of their own adequacy and worth (Restubog et al., 2008: 1396). It has also been found that employee preferences for certain psychological contracts are influenced by their self-concept and therefore linked to different preferences for what they may look for in an ideal psychological contract (Low et al., 2016: 1460). Identity issues may also be involved in the more relational aspects of psychological contracts, with studies finding that most contracts contain a core of transactional aspects related to economic exchanges, but that the more valued dimensions 
include relational aspects, such as support in dealing with personal problems (Coyle-Shapiro and Kessler, 2000: 906). Relational aspects have been linked to socio-emotional dimensions like growth, status, commitment and identification (Chambel and Alcover, 2011: 117) and their violations to "more symbolic responses" (Restubog et al., 2008: 1382).

However, how all of this, and psychological contracts in general, can be understood in the context of ongoing identity work has not been elaborated. Prior research on identity has highlighted identity work as a complex process in which symbolic resources are utilized by individuals to "secure a sense of self" (Brannan, Parsons and Priola, 2015: 33). Organizations are viewed as providing multiple and polyphonic discourses on which individuals draw as “important symbolic resources for identity negotiation" (Kornberger and Brown, 2007: 499) used to construct "preferred versions" (Kornberger and Brown, 2007: 500) of the self. Work from this perspective is both the experience of a sense of continuity of the self as well as its frequent disruption (Grote and Raeder, 2009: 222). Crucially, identity work involves internal struggles with unconscious subjectivity and desire (Arnaud and Vanheule, 2007).

How this, in turn, functions in the context of psychological contracts is what I hope to explore further here. Specifically, my aim is to build on Meckler et al.'s project (2003) to reinvigorate psychological contract research by reintegrating its original psychoanalyticallyinformed perspective (Meckler et al., 2003: 220). The aim is to provide novel perspectives on the psychological contract that can account for less conscious dynamics of identity work, and do so in the context of organizational power, control and resistance (Brown and Lewis, 2011).

\section{Lacanian Conceptions of the Self}

It might strike some as ironic to bring Lacanian psychoanalysis to bear on this debate. Hardly anywhere is the relationship between psychology and psychoanalysis more fraught with 
difficulty as when it comes to Lacanian conceptions, with some suggesting that: "Psychology is part of the imaginary reality of capitalism, which Lacanian psychoanalysis unravels" (Parker, 2011: 105). Especially when it comes to the psychological contract, one might suspect that Lacan would consider it not only imaginary but further proof that this reduces the human, qua human resource management, "to a strategically manageable veneer" (Johnsen and Gudmand-Hoyer, 2010: 333). Consequently, from a Lacanian perspective, the psychological contract might be dismissed as a prototype of "psychological models...aim[ing] to adapt each individual to relations with others that are based on contractual obligations" (Parker, 2011: 106). However, what I aim to highlight here is that Lacanian conceptions of subjectivity have much to offer for a more complex understanding of the psychological contract, especially the role it has come to play in articulating the employment relationship.

Illustrated by their contributions to several areas of organizational inquiry, e.g. HRM practices (Johnsen and Gudmand-Hoyer, 2010), burnout (Vanheule, Lievrouw and Verhaeghe, 2003) and trust (Driver, 2015), Lacanian conceptions of subjectivity offer a unique understanding of the narrative construction and malleability of the self (Rousseau, 2003: 232). In particular, they explore the idea of fundamental lack at the heart of human experience. This lack is related to the division between the self, or identity, individuals consciously articulate and who they are as a function of unconscious desire (Lacan, 1977a;b; 1988a;b; 1991; 2001). Identity work is always unsettled as it straddles a number of conflicting orders. There is the order of the real (Lacan, 1988b: 210) or that which we might really desire or seek to articulate. Unfortunately, we are always cut off from the real as we can only express ourselves through language, or, what Lacan calls, the symbolic order (Lacan, 1988b: 210). The latter encompasses our social order and the linguistic conventions by which we communicate (Lacan, 1977b: 245). 
None of this expresses who we really are or what we really want. Hence, we experience anxiety that the ego defends against by making believe that we can still get at the real. This then enmeshes us in, what Lacan calls, the imaginary order (Lacan, 1988b: 177) in which we can articulate a self that knows who it is and can obtain what it wants. This is the order of common speech and, what we might refer to as, routine identity narration, in which we can cover over any underlying lack and feel complete. Yet, if one listens more closely to such ordinary identity narratives, it becomes apparent that we get routinely bogged down by our inability to say exactly what we wish to say. This is evidenced by numerous tensions, contradictions and other ambiguous rhetorical creations that unsettle our imaginary constructions and reiterate fundamental lack (Benvenuto and Kennedy, 1986: 13). Rather than articulating who we really are, we instead reiterate misrecognition, alienation and otherness and not our own but others' desires, or, what Lacan calls, the Other (Lacan, 1977b: 214). We chase this Other and yet only arrive at nothingness. We express a "desire for nothing" (Lacan, 1988b: 211) because even if we get what we want, it often leaves us dissatisfied (Lacan, 1977b: 268).

Perhaps surprisingly the solution for all of this, from a Lacanian perspective, is not that we somehow rid ourselves of the imaginary and learn to get to what is real. This remains an impossibility (Muller and Richardson, 1982: 373) and a structural obstacle we cannot overcome (Lacan, 1988b: 210). Instead, we have to learn to appreciate the inevitable failures of the imaginary (Lacan, 1977b: 218) as a liberating and empowering dynamic. Our inability to get to the real is an engine of power that drives us on, a struggle that makes us creative (Fink, 2004: 62) and also liberates us, at moments, from the imaginary (Lacan, 1988a: 285). At such moments, we can enjoy desire for its own sake (Lacan, 1977b: 243) and make the real present as an absence (Ragland, 1996: 200). Individuals achieve "a sense of self" (Lacan, 1988b: 223) through the 
experience of lack that drives them on to articulate a self. This self is always unsettled, but also powerful and creative. It is a "subjectivity in revolution" (Parker, 2011: 199) fading in and out of view at the site of disruptions of the imaginary.

The question then becomes how to deal with such disruptions and what position to take toward underlying lack, such as imaginary versus symbolic responses (Vanheule et al., 2003). On the imaginary side, when we experience disruptions of the imaginary, we see this as a personal problem, which we try to solve by working ever harder to overcome it. This might mean that we work so hard that we eventually burn out (Vanheule et al., 2003) because we can never get to what we really want and the enjoyment we fantasize about (Hoedemaekers, 2009: 190). On the symbolic side, the same experience is seen as a structural problem pointing to transformative alternatives (Vanheule et al., 2003: 335). This means, it becomes possible to work with the structural lack inherent in the employment relationship (Arnaud and Vanheule, 2007: 363) and take different positions toward it (Vanheule et al., 2003: 336). This opens up a wider view of life (Vanheule et al., 2003: 334) as a process of becoming (Fink, 2004: 63). It empowers us to work through fantasies (Hoedemaekers, 2009: 192) and finding our actual enjoyment less paltry as compared to the perfect bliss promised but not attainable (Fink, 2004: 157).

As a result, one way of exploring the unconscious dimensions of psychological contracts (Meckler et al., 2003) is to examine how psychological contracts may become mapped onto struggles with self and desire. Psychological contracts furnish symbolic resources and are part of the discourses that individuals utilize in organizations to construct identities (Kornberger and Brown, 2007: 499). Individuals may draw on such resources to construct an imaginary self, as a conscious attempt to construct a preferred identity, variously unsettled by the impossibility of fulfilling unconscious desire. Lacanian psychoanalysis does not reduce this process to an isolated 
individual phenomenon (Vidaillet and Gamot, 2015: 991). The self can only be articulated through a symbolic order that represents the social and the Other. The latter is also barred from the real and hence has a fundamental lack at its center that is impossible to overcome (Vidaillet and Gamot, 2015: 991). Therefore, Lacanian psychoanalysis also points to the inherent political dimensions of identity work as we do things with discourse (Edwards, 1997: 20) while our agency is constrained by the social and political through which we enact it.

\section{Empirical Material and Interpretive Methods}

I now explore how all of this might inform our understanding of how psychological contracts function in the context of identity work. As this is a subjective and narrative process, I heeded the call for more qualitative research into the psychological contract (O'Leary-Kelly et al., 2014: 328) and employed a storytelling methodology (Gabriel, 1991; 1995) particularly suited to explore the narrative construction of the self, with both conscious and unconscious dynamics. The terms story and narrative are used interchangeably with organizational stories often being terser than traditional stories (Boje, 1995) while still fulfilling the role of narratives (Czarniawska, 1998) as "a discursive ordering of events" (Lawrence and Maitlis, 2012: 647) socially constructing feelings, actions and relationships in meaningful ways.

Purposeful sampling (Glaser, 1978) was employed to enlist the participation of members of various organizations. Specifically, alumni of my institution were contacted to see if they wished to participate and asked, in snowball fashion (Pole and Lampard, 2002), to provide additional contacts in their networks. As I was interested in a broad perspective on how psychological contracts may function in the context of identity work, I was not looking for members of particular organizations. Rather I was hoping to get a broad spectrum of participants with a wide range of psychological contracts across positions, organizations and industries. 
Potential respondents were asked to share a story illustrative of a psychological contract they have, or had, with a current, or former, employer. The relationship to respondents was one of sharing a journey as "fellow traveler[s]" (Gabriel, 1995: 481) with interest signaled in subjective meaning making (Gabriel, 1991: 871). Therefore, no predetermined questions were asked. The psychological contract was referred to as the unwritten and informal expectations that exist between the narrator and his/her employer, such as all the things that are not in the employment contract, or explicitly spelled out, but that one thinks one's employer owes one, and vice versa. Participants were asked to share any story that might illustrate such expectations and to write and email it. As in prior research, written stories are an acceptable means for engaging respondents in rich reflective practices (Gabriel, 2000) with electronic collection, like online surveys, being a convenient way for research participation (Kiewitz et al., 2009: 811). 106 individuals agreed to share their stories, 47 of which are female, 59 male. Positions held vary from frontline employee, to manager, and executive across a wide sector of occupations and industries, such as finance, manufacturing, construction, healthcare, retail, hospitality, public service, education, sevice, agriculture, energy, media and defense. Any identifying information has been removed.

The stories were analyzed using qualitative narrative inquiry (Morison and Macleod, 2013; Ollerenshaw and Creswell, 2002; Polkinghorne, 2007; Sermijn et al., 2008; Rogan and De Kock, 2005). This framework is appropriate for exploring narrative constructions of the self providing space for subjects (Wolgemuth and Donohue, 2006) while not objectifying and claiming them (Tuck and Yang, 2014: 814). This method of data analysis stresses complex processes of meaning-making and the fluidity and contingency of identity narratives (Wolgemuth and Donohue, 2006). The narratives were approached not as a gateway to an underlying objective truth but as linguistic struggles (Hoedemakers and Keegan, 2010: 1028) 
with multiple and shifting significations. Each narrative has multiple points from which an analysis can begin as a "creative endeavor" (Ybema, Keenoy and Oswick, 2009: 316) through which potentially transformative readings can emerge (Sermijn et al., 2008).

The analysis proceeded in iterations going from the literature to the narratives and back (Corbin and Strauss, 2008; Eisenhardt, 1989) reflexively moving between different perspectives, focusing on meanings made but also on critical attempts to situate them in existing power structures (Alvesson and Skoldberg, 2000: 289). It moved from more "descriptive coding" (Lilius et al., 2011: 878) noting respondents' gender, occupation and industry to "broader interpretive questions" (Lilius et al., 2011: 878), such as whether the story was about an intact or breached psychological contract, what type of contract was described, such as transactional or relational, and if and how it was breached. I then explored how its discursive resources were drawn on to do identity work (Alvesson et al., 2008) reflexively moving (Alvesson and Skoldberg, 2000) toward a psychoanalytic perspective (Parker, 2005) exploring imaginary selfconstructions (Driver, 2009) and imaginary and symbolic responses (Vanheule et al., 2003: 334). The goal was to develop interesting new arguments in the ongoing debate (Alvesson and Skoldberg, 2000: 276) over richer conceptualizations of psychological contracts (Conway and Briner, 2009), while recognizing the analysis as an "incomplete, contingent and corrigible activity" (Parker, 2005: 176). In what follows, I try to balance a focus on the contingency of positions in discourse (Thompson and Willmott, 2015) with humility and respect for the narrators' often painful experiences and the meanings made from them (Hendry, 2007: 494).

\section{Psychological Contracts and the Imaginary}

The narrative excerpts I analyze below were chosen because they highlight key aspects of the complexities of how psychological contracts unfold as a process of doing identity work, 
underlining its unconscious aspects (Meckler et al., 2003). Specifically, the aim is to highlight how psychological contracts may be analyzed from a Lacanian perspective by following carefully how imaginary selves are constructed and how narrators respond when such constructions are unsettled, tracing a movement from imaginary toward symbolic positions. I begin by examining narratives in which narrators take a more imaginary stance by which they either do not acknowledge underlying lack or seek to cover it over (Vanheule et al., 2003). Dana, an operations manager describes her psychological contract: "I'm a young, ambitious leader... I want knowledge, skills, and experience that will help me grow professionally and personally...It's rewarding to do my job well and be respected by my peers. It's also a validation that I'm a strong employee and resource, which gives me a lot of satisfaction...I am constantly getting feedback [and] compliments on how well I do my job and how I should be getting a higher salary, which makes me happy that people can see my hard work... What my employer owes me besides formal rewards, I believe, are respect, trust and good communication (12)."

Dana describes what seems to be an intact, relational psychological contract in which she works hard in exchange for growth, recognition and respect. She draws on the discursive resources provided by this contract to construct an imaginary self as someone who is an ambitious leader, and a strong, hardworking employee. The discourse of ambition and hard work is likely part of commonly available, or even dominant, discourses offered by her employer and part of the power and social order to which she is subjected as she constructs her preferred self.

This self is unsettled as she refers to others underlining that she ought to get more pay, suggesting that her employer may not value her as much as she may believe. But such lack is not acknowledged by Dana saying that she is just happy to be recognized for her efforts. As she draws again on the discourse of hard work, it may be that this discourse is particularly dominant 
in her organization or that she does not wish to move away from her position toward this discourse (Brown and Lewis, 2011: 874). Consciously this discourse may align with her preferred self. It may also provide her with a way to maintain an imaginary stance toward underlying lack. In this sense, the lack expressed is covered over in a way to strengthen the fantasy that work can render her complete. The lack of appreciation that lower pay may signal is covered over by expressing her happiness in being recognized as a hardworking employee. Although there is a hint here that Dana is not succeeding in fulfilling the Other's desire, this otherness is glossed over. Her psychological contract keeps her stuck in an imaginary position in which its inevitable disruptions cannot be acknowledged. It does so not only through the enforcement of discursive regimes that may keep individuals stuck in organizationally-preferred versions of themselves (Kornberger and Brown, 2007: 500), but also because this becomes mapped onto the maintenance of the fantasy of completion (Hoedemaekers, 2009: 182).

We see this in Larry's narrative who is a public service employee and describes his psychological contract as follows: "My psychological contract is not only to fulfill my defined functions, but to act in such a way as to advance our company's goals in whatever capacity I can...In some cases, I believe I have higher expectation of myself and my contributions than the company has of me...this has a positive effect on me as I feel I am making valuable contributions...I feel that any breach of the psychological contract has been the result of my actions by choosing to put more effort into my responsibilities than what is expected of me...But even during times of high stress and long hours I still have very positive feelings about my company...This is not to say the company does not have high expectations for all employees. I just don't believe they are unreasonable...I have positive perceptions of my organization and this actually makes me want to work harder (19)." 
Larry draws on the discursive resources provided by his psychological contract to construct an imaginary self as someone who not only fulfills his psychological contract for his employer but goes above and beyond what may be expected of him. While this makes him feel valuable and inspires him to work harder, we can see how this also unsettles his imaginary construction. He refers to a breach of his psychological contract, the stress his work causes him and his family, and the high expectations placed on him. He covers over this underlying lack by asserting that it is he, and not only his employer, who places strong demands on him. Like Dana, Larry seems to align his preferred self with dominant managerialist discourses (Hoedemaekers, 2009: 182) in his organization and as such is stuck in an imaginary order in which lack has to be covered over to maintain the fantasy that work can render the self complete.

Of course, this does not keep lack from resurfacing. The tensions in his narrative only reinforce that he may not know himself as much as he says nor obtain what he desires. Moreover, by asserting that he feels very positively about his employer, we suspect that he may not do just that. When he ends by saying that he will work even harder, we see how precarious his imaginary order is, yet also how stuck he seems to be in it. As long as his psychological contract furnishes him discursive resources to construct an imaginary self, he considers it intact and is stuck in an identity that allows little room for agential play (Brown and Lewis, 2011: 874).

This dynamic also comes into view in James' story. James is a professor: "My job is more than just my job. It is my life, who I am...Even when I am at home I am at work...Working with some of my colleagues makes my job difficult because of a power struggle and lack of respect, which can make the atmosphere somewhat hostile. I just go back to my students when this happens, I do it for them and it is okay because that is who I am and that is my purpose...I see myself as a loving, caring, encouraging and sometimes stern parent to 
hundreds of students...I am identified by it in the community as well. I am the professor...I live my job in my whole life... That is important to me because I am honored to have the job and it shows off my hard work...It helps build respect...I do it because it makes me happy (31).”

While James experiences breaches of his psychological contract around how he is treated by coworkers, he does not consider this psychological contract unsustainable. On the contrary, such difficulties are seen to furnish more discursive resources to construct an imaginary self as a caring parent to "hundreds of students". This validates his self while covering over any lack he may experience from the disrespect and hostility in his work environment. Like Dana and Larry, James seems very much a psychological contract-taker. He aligns his preferred self with organizational discourses that are likely dominant in his institution, such as developing close relationships with students and being a caring professor.

James's narrative also illustrates well an imaginary stance toward underlying lack in that the unsettling of his imaginary self through various breaches is not only covered over but also reinforces his imaginary order. For instance, despite a hostile atmosphere, he hangs on to being loving; and despite the lack of respect, he suggests that his hard work is building respect. In James' imaginary order such tensions are not explored. Instead, he asserts that through his work he can find happiness and feel so complete that his work is his life. In taking an imaginary stance, James can draw on the discursive resources from his psychological contract and use the lack that surfaces to keep the fantasy alive that work can render him whole.

Maintaining such an imaginary stance may become difficult when the disruptions of the imaginary become severe or are perceived to be more threatening by the narrator. This seems to be the case in Carl's narrative. Carl is a software marketer. "When I accepted the job, I was aware I would have more responsibility as I have a whole team of people to account for...I enjoy 
the rewards I receive for this and the team I work with. What I was not prepared for was the rapid fluctuation of demands I receive. I'm very stressed in my current situation and feel like my psychological contract is being violated. My workload has increased tenfold from what it was before and there is no consideration from my boss about how I feel about it. I am simply expected to cope...I feel used and taken advantage of (27)."

What we see here is how Carl not only describes psychological contract violations but also how this makes it much more difficult for the narrator to construct an imaginary self. When he says, he feels used and taken advantage of, we can hear underlying lack surface as if his imaginary self is profoundly unsettled. In this sense, his psychological contract perhaps does not provide him sufficient discursive resources to construct an imaginary self and is no longer intact. We see a fundamental unsettling of the imaginary that he does not seem able to repair. Yet, we do not see any attempt to take a more symbolic stance. Rather, like previous narrators, we see Carl hang on to the idea that he can find what he is looking for in his work. He also hangs on to the hope that his supervisor cares about how stressed he is. In so doing, he draws from a dominant discourse that employers not only reward employees but value them in special ways. In this sense, the violation of his psychological contract sends the symbolic message to him that he is not valued by his employer but it does not move him toward abandoning the fantasy that he could be valued and rendered complete if only his employer corrected the current situation.

Marie, a hospitality industry employee, seems to be in a similar situation: "I considered my boss my best friend... She did things that pissed me off but I got over it for the first three years. After that she hired a new manager so she didn't need me as much...Last year things got really bad. I was already sick with lupus and as I got sicker she got ruder... When I told her I was sick, I still had to go to work for her to see how sick I was...She treated me like shit...she used 
me. When I was used up, I was treated like nothing...I lost my job, my home, my car, and most of my belongings. I lost everything. I went from everything to nothing. I feel useless. What did I do everything for? When I was working I felt successful. Now it's like I have no purpose (4)."

What comes through in Marie's narrative is how her imaginary self-constructions can no longer be repaired given the discursive resources of her current psychological contract. While at first, it apparently offered such resources, as Marie describes herself as having had "everything". Now, she describes herself as being used up, feeling useless and having no purpose. Marie is clearly unable to cover over the lack that so surfaces, and is confronted with a dead end. The imaginary has been completely disrupted and she can no longer construct herself as successful and fulfilled through her work. Yet, Marie is taking an imaginary position toward this lack and therefore continues to be stuck in an imaginary order she wishes to repair and is unable to let go of. Marie may continue to believe that work can restore her imaginary self, and as such continue to hold out for the promise that work can render the self whole. In this sense, it is a more generic psychological contract of expecting to find fulfilment through work (Hoedemaekers, 2009: 192) that limits her ability to explore a moving-on identity narrative (Fraher and Gabriel, 2014: 940) and widen a space of resistance (Vidaillet and Gamot, 2015: 992).

The latter can be further illustrated in Rob's story. Rob works as a pipe fitter installing sprinkler systems: "I'm everyone else's bitch. I do whatever I'm told because I'm the lowest guy on the totem pole. I am only working this job for money. I can't say, I really like what I do. The only part I like is I feel I help protect people and their businesses from fires. At the end of the day I'm looking for a job where I'm treated like a person not a tool or a machine (22)." Rob's psychological contract does not just seem to disrupt his imaginary order but rather to offer him insufficient discursive resources to cover over lack. He seems to describe a transactional 
psychological contract centering on an economic exchange with few symbolic resources to construct a desired identity. Yet even here there are resources to construct an imaginary self, one that finds satisfaction in the money he earns and protecting people from fires.

Importantly, Rob remains stuck in an imaginary order in which he finds fulfillment in work as he continues to look for a job in which he is not treated as he is now. Like Marie, it is as if Rob continues to draw resources from some imaginary psychological contract, a generalized contract of what work ought to offer. This allows him to take an imaginary stance to what he experiences by which underlying lack can continue to be covered over and the fantasy can be maintained that work can render the self whole. This imaginary stance keeps Rob stuck as a psychological contract-taker, and, no matter how transactional or violated his current contract may be, his agency seems reduced to waiting for the right psychological contract that another "better" organization will surely offer him.

\section{Psychological Contracts and the Symbolic}

So far, we have seen narrators construct imaginary selves from resources offered by their psychological contracts remaining enmeshed in an imaginary order even when such constructions are unsettled. I now explore how other narrators take a more symbolic stance to such disruptions whereby they can depersonalize them as structural conditions. We see this in the next narrative by Gaye who works as a service employee and describes her psychological contract as follows: "When I began working for my employer, I was very excited for many reasons. I had visions of helping coworkers, selling our product to the public, self-gratification of doing an excellent job, etc....I had set my own self-expectations to go above and beyond the basic duties and prove to my employer that I was the best person for the job and that they had made an excellent decision in selecting me...The first few months were very challenging and 
eye-opening! I really stepped out of my comfort zone and worked even harder...I have now worked for my employer 14 plus years and have realized a few things. I have learned to accept things I cannot control, like people's opinions or expectations, and that I can still have selfexpectations to be an excellent employee and succeed on my own terms (77).”

This narrative illustrates how an intact, relational psychological contract can furnish resources to both construct an imaginary self as well as to take a more symbolic stance when the imaginary is disrupted and expectations of wholeness are not being met. While Gaye does not describe the latter in detail, we can see how she uses the discursive resources offered by her psychological contract to construct an imaginary self as the excellent employee who exceeds her employer's expectations. Apparently, this imaginary self was unsettled as she was pushed out of her comfort zone and had to work even harder to maintain it. However, rather than continuing to repair the imaginary by seeking to align her self-expectations with her employer's, she learned to let go of others' expectations formulating her own expectations around what she considers to be successful. Unlike Dana, Larry or Rob, Gaye engages in more agential playfulness (Brown and Lewis, 2011: 874) with the dominant discourses in her organization. She carves out a space in which to use the discursive resources provided by her psychological contract to open up her identity work (Fraher and Gabriel, 2014: 940) and disinvest from some of the employer-provided resources aligning herself less with an employer-sanctioned self (Knights and Clarke, 2014: 338). It may be that the discursive regimes offered by her employer lose their effectiveness over time, or that some of the experiences she describes as "eye opening" allowed her to amplify rather than cover over underlying lack. Gaye depersonalizes some of her difficulties and perhaps engages in micro-resistance (Thomas and Davies, 2005) as she reshapes her organization's dominant discourse of hard work and excellence to better fit with her own experience. 
A similar dynamic comes through in the next narrative. JP is a stock trader who enjoys the terms of his current psychological contract, but is ready to leave his job because he feels that it does not provide adequate resources for identity work: "I work at a good company not really doing what I love but I have a very stable job...I don't like the negative connotations that come with this job...I constantly feel like I have to defend myself when I tell people what I do for work. People often assume I'm just trying to get rich when really I'm just trying to support my family...I really enjoy my job...but it is not what I expected to do with my life...I'm going to continue working for them until the right opportunity comes along that allows me to make my passion my career (23)."

JP describes an intact relational psychological contract and his employer as "a good company". The reason this psychological contract is not sustainable for him, however, is because it is not what he loves and wants to do with his life. This still leaves him with an imaginary selfconstruction as someone who knows who he is and can find what he desires. But the unsettling of the imaginary, in that his current work does not seem to validate who he sees himself as being, opens up a space for him to play creatively with the discursive resources offered by his psychological contract. While JP is still firmly stuck in the fantasy that work, just not his current job, can provide him fulfilment, this creates a space to disinvest from the employer-sanctioned self as a loyal and committed employee who will remain.

Importantly, it offers a more symbolic stance in that lack is not only covered over but rather provides the impetus to move on and question who he is and what he may wish to get out of work. Therefore, like Gaye, JP is able to widen the space in which he exerts agency, becoming more of a contract-maker than a contract-taker. Despite having an intact psychological contract, JP is not stuck with an employer-provided preferred self, and, instead, can think about ways in 
which he would like to move on. Like for Gaye, it is not clear what allows him to have this more empowering stance. Perhaps, it is simply a question of amplifying that the employer-provided discursive resources no longer allow him to maintain the fantasy that this particular organization can render him complete.

We can see a similar dynamic in Kelsey's narrative. She works as a director of events in a not-for-profit firm: "There are challenges in my workplace that I have had to learn to navigate... Our Executive Director, for example, is very difficult to deal with... she puts things off until they become critical and then gets nasty while we try to rush it. Then there are lots of unspoken expectations about how much time we have to spend at work... Two people have already quit because they couldn't deal with her moodiness...All in all, it's still a good job and I strive to do it well. But I have had to learn not to take things personally and that frustration is part of dealing with other people. I try not to get mad about it. After all, they would not call it "work" if it was all fun (56)."

Kelsey constructs an imaginary self as someone who likes her job and is good at it. Yet, we can see how much in her work is not to like and how her imaginary self does not seem validated. Despite breaches of her relational psychological contract, rather than seeking to repair the imaginary, Kelsey seems to take a more symbolic stance. She acknowledges the frustrations as part of work and thereby depersonalizes the disruptions of the imaginary she experiences. By not articulating how she hopes for a better job that can provide her with imaginary fulfillment, she is also working through the fantasy that work can offer this in the first place. When she says that work would not be called work if it was all fun, perhaps she is divesting herself not only from her employer-sanctioned self but also from the fantasy that work can fulfill the self. This is perhaps also why her psychological contract is not described as violated, but rather that she can 
make do with the enjoyment that is left when she no longer compares it to fantastical bliss. Her job is "good", in that it is as "good" as any other.

Unlike JP therefore, Kelsey does not use the disruptions of the imaginary in her current psychological contract to further cement the fantasy that she can be rendered whole through work if she only had a better psychological contract or one with a different employer. Kelsey's moving on is different from JP's. JP hopes to move on to another organization and, in this sense, is a contract-maker in his current organization but perhaps still a contract-taker in future.

Meanwhile, Kelsey is moving on while staying with her current employer, being a contractmaker in future as well, as she is not hoping to find fulfillment then either. This empowers Kelsey in that she can play more with any discursive resources on offer independently of the employer she works for and continue to work through the fantasy, as an ongoing process and journey of becoming (Fink, 2004: 63).

We can see a similar process in the next narrative in which the narrator draws discursive resources not, as Kelsey did, from contract breaches, but rather from an intact contract with a different employer after a violation by a former employer. Frank is an airline pilot: "I thought I could actually relax a little after spending the last 15 years struggling to get to a major airline with some stability and job security. 9/11/2001 changed all that... all of a sudden 10,000 airline pilots were out of a job...I started looking for a flying job immediately...but nothing was available...I lost my dream job...No job, no wife, no dog, no home and yet 6 months before I had the world in the palm of my hand and the future looked so bright! I really felt lost. My whole identity was: 'Frank, the airline pilot'...I desperately tried to find a job flying anything...It was one of the darkest periods in my life...my friends and I who were furloughed... were constantly preoccupied with 'our lives are on pause' mode of living. It was the wrong way to 
live...Eventually I was recalled...I found that having a working psychological contract with [name of airline] wasn't the key to my happiness. It was just being in a place that I fought for for so long. A place that I had built into my mind where I could be happy again...I realized I had wasted the last six years worrying about getting back... when I should have enjoyed and become more engaged with the people I met, and spent more time with my family (7)."

Validating research on the identity work of major airline pilots (Fraher and Gabriel, 2014), Frank was stuck in an imaginary order in which he was "Frank, the airline pilot", having attained everything he ever wanted. This imaginary construction persisted even after he was laid off and led to him being stuck in an identity that did not allow him to respond to his circumstances in constructive ways (Fraher and Gabriel, 2014: 940). As he says, he put his life on hold for 15 years and his imaginary self-construction persisted while he drew discursive resources from a violated psychological contract to hang on to it. Only after he returns to an intact psychological contract does he draw on its discursive resources to take a more symbolic stance. When he realizes that he was stuck, he constructs a rather different self, one that can move on and become more open to different experiences. This also allows him to work through the fantasy that work can offer him the kind of fulfillment he had been looking for. As he disinvests from this fantasy, he can enjoy his life for what it might offer, when it is not constantly devalued by the fantastical bliss he was holding out for, and that is so much at the heart of the promises made by employers about what work can offer (Hoedemaekers, 2009: 190).

Like Kelsey, Frank is becoming a psychological contract-maker beyond the confines of whatever contract is on offer in his current job. Like Gaye, he can draw on his experience to take a different position toward the continuous unsettling of the imaginary and, unlike like Dana and Carl, Frank can divest himself from being a psychological contract-taker always hoping that the 
"right" contract is ready to be realized. In this sense, Frank no longer invests in employersanctioned versions of the self. He redefines what it means to have an intact psychological contract, one in which he is free to disinvest while still enjoying what it has to offer.

\section{Discussion}

What I have tried to illustrate so far are the complexities involved as individuals draw on the discursive resources provided by their psychological contracts to do identity work. As we have seen, psychological contracts can furnish symbolic resources that allow not only the construction of selves, who know who they are and can obtain what they want, but also the taking of an imaginary stance to their inevitable disruption. Whether a psychological contract is breached or intact, or simply does not seem to furnish the discursive resources to construct, or maintain, a desired self-concept, as prior research has underlined (Kiewitz et al., 2009: 810; Restubog et al., 2008: 1396), an imaginary stance may be taken by which the fantasy is maintained that it can do so. That is, whether intact or otherwise, a psychological contract can render individuals stuck in the imaginary, in which underlying lack is covered over. As we have seen, several narrators either do not acknowledge the tensions that unsettle their imaginary selfconstructions, seek to repair them, or find the imaginary self to be strengthened by underlying contradictions. From this vantage point, it is irrelevant to an extent whether the psychological contract is intact or breached, relational or transactional. While intact relational psychological contracts seem to make it easier to construct an imaginary self that experiences little unsettlement, even these can disrupt the imaginary. The same is the case for breached relational contracts, which can still reinforce an imaginary stance and the maintenance of underlying fantasies. 
Consequently, it is less the psychological contract driving identity work as identity work driving the psychological contract. In prior research, this relationship has been under-researched or oversimplified in the sense that an intact contract validates the self while a breached one does not (Kiewitz et al., 2009: 810; Restubog et al., 2008: 1396). However, when looking at the narratives analyzed here, it seems that employees are much more contract-makers than takers in how psychological contracts are mapped on to struggles with the self and desire. Importantly, it seems to be employees who determine how empowering their contracts are.

On the one hand, it is empowering to extract discursive resources from psychological contracts to construct imaginary selves. Without such constructions underlying lack cannot surface and one cannot connect to the real as an absence made present (Ragland, 1996: 200). However, this can also lead to taking an imaginary stance and getting further enmeshed in an imaginary order in which one is more alienated from unconscious subjectivity. This may make individuals more vulnerable to exploitation (Hoedemaekers, 2009: 194). It may also render them stuck not only in potentially dysfunctional identity narratives (Fraher and Gabriel, 2014: 941) but also ones that are more aligned with organizationally-sanctioned selves (Kornberger and Brown, 2007: 500). Put differently, individuals seem more likely to be subjugated by dominant discursive regimes when the resources they extract from them are mapped onto an imaginary stance that further reinforces the fantasy that work can provide the fulfillment they long for. Consequently, it is not the type of psychological contract on offer, or even the common experience of its violation in the context of the erosion of the employment relationship (CoyleShapiro and Kessler, 2000: 904), that disempowers individuals into being contract-takers. While some discursive regimes and some psychological contracts, such as intact relational ones, may seem more conducive to becoming stuck in an imaginary order, it is how individuals move along 
a continuum from imaginary to symbolic that drives whether they are, in this sense, contracttakers or makers.

However, while it may be empowering to take a more symbolic stance toward lack, this is perhaps not a movement that is final or linear, in the sense that one is always in one place or another. As we have seen, several narrators, whether they articulate an intact or breached psychological contract, use discursive resources to take a more symbolic stance to underlying tensions but oscillate between various imaginary constructions that continue to be unsettled. Some of them consider breaches of their psychological contracts as an opportunity to reposition themselves toward lack as a structural condition. They may narrate more open identities that can move on from imaginary self-constructions while playing with discursive resources in transformational ways. Some of them will do this in an intact psychological contract as well, creating a space in which to depersonalize inevitable difficulties while seeking to carve out new relationships to self and work (Arnaud and Vanheule, 2007). In this way, psychological contracts can furnish resources to work through the fantasy that work can complete the self as a continuous process, not a linear accomplishment (Hoedemaekers, 2009: 194).

This is not to overstate the implications of this for the distribution of power in organizations. As has been noted, employers have largely more power to negotiate the terms of the psychological contract (Conway and Briner, 2009: 168) and, as we have seen, many narrators are coping with broken psychological contracts. They endure a great deal of anxiety and pain when contracts are violated, as in Marie's moving story of loss. Their attachment to a specific imaginary self-construction keeps them stuck in a given identity. It also glosses over various contradictions in the social logics to which they are subjected (Thompson and Willmott, 2015), such as putting up with increasing employer demands, excessive workloads, arbitrary treatment 
and lack of respect. So, pointing to empowerment and agency does not necessarily imply the possession of organizational resources and power (Lam and de Campos, 2015: 836).

However, it does point to the agency and power inherent in the contingency of subject positions in discourse and, therefore, the ability to unsettle existing social logics by opening a space for alternative ones (Thompson and Willmott, 2015). As we have seen, several of the narrators, like Gaye and Frank, who take a more symbolic stance, can reflect on alternate selves. They can also disinvest from employer-sanctioned identity work and, perhaps, identity work more generally (Alvesson and Robertson, 2016). From this perspective, the narration of psychological contracts is both a process of further subjugation as well as resistance to discursive regimes. But this is not independent of the struggle with unconscious subjectivity. Subjugation is leveraged through an imaginary position, while emancipation moves through a symbolic stance.

This, in turn, opens up a much more complex and processual understanding of the psychological contract that can accommodate not only unconscious aspects but also how the social and the political work through the doing of identity work. Perhaps the time has come to view the psychological contract from this perspective and move away from well-rehearsed dichotomies, such as intact versus broken, and transactional versus relational. A psychoanalytic perspective suggests instead the idea of tracing the narration of psychological contracts along the continuum from imaginary toward symbolic as a process of taking different positions toward the disruptions of the imaginary. This shifts the focus from observing whether a contract is working or not toward exploring the process of how all psychological contracts are working in different ways as they become mapped on to struggles with self and desire. Rather than seeking to explore exclusively how psychological contracts fulfill promises and needs, conscious or otherwise (Meckler et al., 2003: 222), it may be time to explore how they necessarily fail to do so. 
A psychoanalytic perspective on the psychological contract highlights that, as the employment relationship changes, it may become more about doing work for subjects than organizations (Arnaud, 2007). Identity work, in this sense, is not related to psychological contracts in linear fashion whereby individuals rely on intact relational contracts to stabilize a preferred self and vice versa. This suggests that it may be an oversimplification to view employees as both contract and identity-takers and to make linear predictions about how violations of psychological contracts may be experienced by employees in organizations today. Violations may not always entail identity threats nor do intact contracts necessarily stabilize identity or require that employees conform to organizationally-preferred versions of the self. This perspective offers novel vantage points to explore power and resistance in organizations. On the one hand, the agency of what individuals do with discourse is always constrained (Brown and Lewis, 2011: 874), which psychological contract research has underlined by focusing on its social and economic dimensions (Meckler et al. 2003: 218). It is little surprising that, therefore, this research is said to have a managerialist bias focusing on how individuals are rather disempowered as contract-takers (Lam and de Campos, 2015: 814; O’Leary-Kelly et al., 2014: 351). When focusing psychological contract research on its unconscious dimensions, this appears to be oversimplified.

Specifically, what comes into view by examining psychological contracts in the context of identity work is that individuals may constrain their own agency in the way they position themselves toward underlying lack. As we have seen, some narrators draw more or less on dominant organizational discourses to do so. But even in the best of cases this is already constrained as an imaginary undertaking in which we articulate a self through a symbolic order representing social relations and subjugation to the Other (Vidaillet and Gamot, 2015: 991). 
However, as the imaginary is invariably unsettled, regardless of whether this self is aligned with dominant discourses in organizations via intact psychological contracts or not, we can see how resistance is also a function of how one positions oneself toward such unsettlement. In this sense, resistance is not, or not only, about whether employees obtain a more powerful position in the employment relationship to become contract-makers, but about how they position themselves toward the fantasy that work can render them whole (Hoedemaekers, 2009: 182).

\section{Conclusion}

The aim of the study has been to contribute a novel theoretical perspective on the psychological contract. Specifically, its aim was to build on and revive but also significantly extend its original psychoanalytically-grounded conception, as an agreement to offer the right to employers to use one's productive energy in exchange for the opportunity to fulfill specific unconscious needs, such as affection, dependence and aggression (Meckler et al., 2003: 222). In drawing on a Lacanian perspective, the study instead conceives of unconscious aspects broadly and accommodates more malleable conceptions of self and identity (Rousseau, 2003: 232). It offers a theoretical perspective by which the complexities and the processual nature of psychological contracts can be explored in the context of identity narratives (Conway and Briner, 2009: 144). In so doing, it makes a number of contributions.

First, the study contributes to a revitalization of psychological contract research as a movement away from oversimplified and managerialist conceptions of employees (Conway and Briner, 2009: 144). In this view, they are seen as passive participants in an exchange relationship in which their expectations are frequently not met, driven by their desire for identity security. The latter has been underlined as a potentially self-defeating desire (Knights and Clarke, 2014: 350) rendering employees ever more vulnerable by having to conform to whatever organizational 
ideal is on offer in exchange for validation. While this may be the case when individuals take a more imaginary stance and seek to maintain the fantasy that work can render them complete, the present study advances the idea that the psychological contract may also offer discursive resources for a more empowering stance. Individuals may decouple their identities from psychological contract fulfillment and use contract resources as a space to reflect on "the selfdefeating vicious spiral of ever-intensified preoccupations with identity" (Knights and Clarke, 2014: 348). By moving toward a more symbolic stance, they may trade the identity security provided by an intact contract for more open-ended and decoupled self-constructions.

To undertake research into psychological contracts that accommodates such complexities, it may be important to explore not only what general type of contract individuals have with their employer or whether it is intact or not. Rather, it may be important to explore carefully how, whatever contract the employee has, is narrated in specific instances. Using more varied and qualitative research methods, as has been called for (Conway and Briner, 2009: 144), and as I have tried to adopt here via storytelling for example, offers the opportunity to not only surface less conscious aspects but also to get an understanding of the processes by which psychological contracts unfold over time (Meckler et al., 2003: 223). This shifts the focus from trying to pinpoint what individuals find in their psychological contracts toward exploring what they do not find. In other words, it shifts the focus toward exploring psychological contract narratives in motion, unsettled by various tensions, gaps and omissions. It also facilitates a more dynamic view of how people play with discursive resources (Brown and Lewis, 2011: 874) and thereby assert that the psychological contract may be more meaningful in what it fails to articulate about who we are and what we want. It is in the repeated failures to do so that there is an opportunity for emancipation and a connection to the real as an absence made present (Ragland, 1996: 200). 
Future research could explore this further and examine how the narration of the psychological contract in this context can be seen itself as an act of micro-resistance that unsettles dominant organizational discourses (Thomas and Davies, 2005) as an amplification of lack (Lacan, 1988b: 241). Such amplifications may occur as individuals share their stories with one another and engage in dialogic reflexivity based on interruption rather than interpretation (Lapping, 2016: 721). That is, rather than interpreting what shared narratives, about what employees expect, may mean about psychological contracts, the act of sharing alone may be important. It may interrupt the very idea that we know how to frame those expectations in the context of a secure self with knowable desires. In this way, dominant organizational discourses may be unsettled as acts of "micro-mobilization" (Spicer, Alvesson and Karreman, 2016: 239) in discursive movements from imaginary to symbolic stances toward the increasingly common experience that neither identities nor employment relationships are secure.

Indeed, the perspective advanced here suggests that to explore the complexities of how identity work drives psychological contracts itself undermines the endless and self-defeating “preoccupation with identity" (Knights and Clarke, 2014: 336). Engaging more closely with how individuals appropriate discursive resources from specific psychological contracts underlines that the employment relationship is about experiencing the necessary failure of this preoccupation. Therefore, it is also about doing the work of subjects (Arnaud, 2007) as much as of organizations. Consequently, the study contributes novel perspectives on how identity work is foundational to understanding the processes by which psychological contracts are narrated and unfold. It also provides much-needed and new "working vocabularies" (Meckler et al., 2003: 219) for investigating their socio-economic and political dimensions at the interstice of more complex and less conscious human motivations. 


\section{References}

Alvesson, M., Ashcraft, K.L. and Thomas, R. 2008. Identity matters: Reflections on the construction of identity scholarship in organization studies. Organization, 15(1): 5-28.

Alvesson, M., Robertson, M. 2016. Money matters: Teflonic identity maneuvering in the investment banking sector. Organization Studies, 37(1): 7-34.

Alvesson, M., and Skoldberg, K. 2000. Reflexive Methodology. London: Sage.

Alvesson, M. and Willmott, H. 2002. Identity regulation as organizational control: Producing the appropriate individual. Journal of Management Studies, 39(5): 619-644.

Arnaud, G. 2007. The desire for work: Work motivation viewed from a psychoanalytic perspective. $13^{\text {th }}$ European Congress of Work and Organizational Psychology, Stockholm.

Arnaud, G. and Vanheule, S. 2007. The division of the subject and the organization: A Lacanian approach to subjectivity at work. Journal of Organizational Change Management, 20(3): 359369.

Benvenuto, B. and Kennedy, R. 1986. The works of Jacques Lacan. New York: St. Martin's Press.

Boje, D.M. 1995. Stories of the storytelling organization: A postmodern analysis of Disney as "Tamara-land." Academy of Management Journal, 38: 997-1035.

Brannan, M.J., Parsons, E. and Priola, V. 2015. Brands at work: The search for meaning in mundane work. Organization Studies, 36(1): 29-53.

Brown, A.D. and Lewis, M.A. 2011. Identities, discipline and routines. Organization Studies, 32(7): 871-895.

Chambel, M.J. and Alcover, C.M. 2011. The psychological contract of call-center workers: Employment conditions, satisfaction and civic virtue behaviors. Economic and Industrial Democracy, 32(1): 115-134.

Chaudhry, A. and Song, L.J. 2014. Rethinking psychological contracts in the context of organizational change: The moderating role of social comparison and social exchange. The Journal of Applied Behavioral Science, 50(3): 337-363.

Clarke, C.A., Brown, A.D. and Hailey, V.H. 2009. Working identities? Antagonistic discursive resources and managerial identity. Human Relations, 62(3): 323-352.

Conway, N. and Briner, R.B. 2009. Understanding psychological contracts at work: A critical evaluation of theory and research. New York: Oxford University Press. 
Corbin, J. and Strauss, A. 2008. Basics of qualitative research: Techniques and procedures for developing grounded theory. Thousand Oaks, CA: Sage.

Coyle-Shapiro, J. and Kessler, I. 2000. Consequences of the psychological contract for the employment relationship: A large scale survey. Journal of Management Studies, 37(7): 903-930.

Czarniawska, B. 1998. A narrative approach to organization studies. 1988. London: Sage.

Driver, M. 2009. Struggling with lack: A Lacanian perspective on organizational identity. Organization Studies, 30(1): 55-72.

Driver, M. 2015. How trust functions in the context of identity work. Human Relations, 68(6): 899-923.

Edwards, D. 1997. Discourse and cognition. Thousand Oaks, CA: Sage.

Eisenhardt, K.M. 1989. Building theories from case study research. Academy of Management Review, 14(4): 532-550.

Fink, B. 2004. Lacan to the letter. Minneapolis, MN: University of Minnesota Press.

Fotaki, M., Long, S. and Schwartz, H.S. 2012. What can psychoanalysis offer organization studies today? Taking stock of current developments and thinking about future directions. Organization Studies, 33(9): 1105-1120.

Fraher, A.L. and Gabriel, Y. 2014. Dreaming of flying when grounded: Occupational identity and occupational fantasies of furloughed airline pilots. Journal of Management Studies, 51(6): 926-951.

Gabriel, Y. 1991. Turning facts into stories and stories into facts: A hermeneutic exploration of organizational folklore. Human Relations, 44(8): 857-875.

Gabriel, Y. 1995. The unmanaged organization: stories, fantasies and subjectivity. Organization Studies, (16): 477-502.

Gabriel, Y. 2000 Storytelling in organizations. New York: Oxford University Press.

Gill, M.J. 2015. Elite identity and status anxiety: An interpretive phenomenological analysis of management consultants. Organization, 22(3): 306-325.

Glaser, B.G. 1978. Theoretical sensitivity. Advances in the methodology of grounded theory. Mill Valley, California: Sociology Press.

Grote, G. and Raeder, S. 2009. Careers and identity in flexible working: Do flexible identities fare better? Human Relations, 62(2): 219-244. 
Hendry, P.M. 2007. The future of narrative. Qualitative Inquiry, 13(4): 487-498.

Hoedemaekers, C. 2009. Traversing the empty promise: Management, Subjectivity and the Other's desire. Journal of Organizational Change Management, 22(2): 181-201.

Hoedemakers, C. and Keegan, A. 2010. Performance pinned down: Studying subjectivity and the language of performance. Organization Studies, 31(8): 1021-1044.

Inkson, K. and King, Z. 2011. Contested terrain in careers: A psychological contract model. Human Relations, 64(1): 37-57.

Johnsen, R. and Gudmand-Hoyer, M. 2010. Lacan and the lack of humanity in HRM. Organization, 17(3): 331-344.

Knights, D. and Clarke, C.A. 2014. It's a bittersweet symphony, this life: Fragile academic selves and insecure identities at work. Organization Studies, 35(3): 335-357.

Kiewitz, C., Restubog, S.L.D., Zagenszyk, T. and Hochwarter, W. 2009. The interactive effects of psychological contract breach and organizational politics on perceived organizational support: Evidence from two longitudinal studies. Journal of Management Studies, 46(5): 806-834.

Kornberger, M. and Brown, A.D. 2007. 'Ethics' as a discursive resource for identity work. Human Relations, 60(3): 497-518.

Lacan, J. 1977a. Ecrits. New York: Norton.

Lacan, J. 1977b. The four fundamental concepts of psychoanalysis. London: Hoghart Press.

Lacan, J. 1988a. The seminar of Jacques Lacan, Book I: Freud's papers on technique 1953-1954. New York: Norton.

Lacan, J. 1988b. The seminar of Jacques Lacan, Book II: The ego in Freud's theory and in the technique of psychoanalysis 1954-1955. New York: Norton.

Lacan, J. 1991. Le seminaire de Jacques Lacan 1969-1970, Livre XVII: L’envers de la psychanalyse. Paris: Editions Du Seuil.

Lacan, J. 2001. Autres Ecrits. Paris: Editions Du Seuil.

Lam, A. and de Campos, A. 2015. 'Content to be sad' or 'runaway apprentice'? The psychological contract and career agency of young scientists in the entrepreneurial university. Human Relations, 68(5): 811-841.

Lapping, C. 2016. Reflexivity and fantasy: Surprising encounters from interpretation to interruption. Qualitative Inquiry, 22(9): 718-724. 
Lawrence, T.B. and Maitlis, S. 2012. Care and possibility: Enacting an ethic of care through narrative practice. Academy of Management Review, 37(4): 641-663.

Low, C.H., Bordia, P. and Bordia, S. 2016. What do employees want and why? An exploration of preferred psychological contract elements across career stages. Human Relations, 69(7): 14571481.

Meckler, M., Drake, B.H. and Levinson, H. 2003. Putting psychology back into psychological contracts. Journal of Management Inquiry, 12(3): 217-228.

Morison, T. and Macleod, C. 2013. A performative-performance analytical approach: Infusing Butlerian theory into the narrative-discursive method. Qualitative Inquiry, 19(8): 566-577.

Muller, J.P., and Richardson, W.J. 1982. Lacan and language. New York: International University Press.

O'Leary-Kelly, A.M., Henderson, K.E., Anand, V. and Ashforth, B.E. 2014. Psychological contracts in a nontraditional industry: Exploring the implications for psychological contract development. Group \& Organization Management, 39(3): 326-360.

Ollerenshaw, J. and Creswell, J.W. 2002. Narrative research: A comparison of two restorying data analysis approaches. Qualitative Inquiry, 8(3): 329-347.

Parker, I. 2005. Lacanian discourse analysis in psychology. Theory \& Psychology, 15(2): 163182.

Parker, I. 2011. Lacanian psychoanalysis: Revolutions in subjectivity. New York: Routledge.

Phillipp, B.L.U. and Lopez, P.D.J. 2013. The moderating role of ethical leadership: Investigating relationships among employee psychological contracts, commitment, and citizenship behavior. Journal of Leadership \& Organizational Studies, 20(3): 304-315.

Pole, C.J. and Lampard, R. 2002. Practical social investigation: Qualitative and quantitative methods in social research. Harlow, U.K.: Prentice Hall.

Polkinghorne, D.E. 2007. Validity issues in narrative research. Qualitative Inquiry, 13(4): 471486.

Ragland, E. 1996. An overview of the real, with examples from seminar I. In Feldstein, R., Fink, B., and Jaanus, M. (Eds.) Reading seminars I and II: Lacan's return to Freud. Albany, NY: State University of New York: 192-211.

Restubog, S.L.D., Hornsey, M.J., Bordia, P. and Esposo, S.R. 2008. Effects of psychological contract breach on organizational citizenship behavior: Insights from the group value model. Journal of Management Studies, 45(8): 1377-1400. 
Restubog, S.L.D., Zagenczyk, T.J., Bordia, P., Bordia, S. and Chapman, G.J. 2015. If you wrong us, shall we not revenge? Moderating roles of self-control and perceived aggressive work culture in predicting responses to psychological contract breach. Journal of Management, 41(4): 11321154.

Rogan, A.I. and De Kock, D. M. 2005. Chronicles from the classroom: Making sense of the methodology and methods of narrative analysis. Qualitative Inquiry, 11(4): 628-649.

Rousseau, D.M. 1995. Psychological contracts in organizations: Understanding written and unwritten agreements. Thousand Oaks, CA: Sage.

Rousseau, D.M. 2001. The idiosyncratic deal: Flexibility versus fairness? Organizational Dynamics, 29: 260-273.

Rousseau, D.M. 2003. Extending the psychology of the psychological contract. Journal of Management Inquiry, 12(3): 229-238.

Saville Young, L. 2014. Becoming other to oneself: Misreading the researcher through Lacanian discourse analysis. In Parker, I. and Pavon-Cuellar, D. (Eds.). Lacan, discourse, event: New psychoanalytic approaches to textual indeterminacy. London: Routledge: 223-234.

Sermijn, J., Devlieger, P. and Loots, G. 2008. The narrative construction of the self: Selfhood as a rhizomatic story. Qualitative Inquiry, 14(4): 632-650.

Spicer, A., Alvesson, M. and Karreman, D. 2016. Extending critical performativity. Human Relations, 69(2): 225-249.

Stavrakakis, Y. 2008. Subjectivity and organized other: Between symbolic authority and fantasmatic enjoyment. Organization Studies, 29(7): 1037-1059.

Thomas, R. and Davies, A. 2005. Theorizing the micro-politics of resistance: New public management and managerial identities in the UK public services. Organization Studies, 26(5): 683-706.

Thompson, M. and Willmott, H. 2015. The social potency of affect: Identification and power in the immanent structuring of practice. Human Relations, 68: 1-24.

Tuck, E. and Yang, K.W. 2014. Unbecoming claims: Pedagogies of refusal in qualitative research. Qualitative Inquiry, 20(6): 811-818.

Turnley, W.H. and Feldman, D.C. 1999. The impact of psychological contract violations on exit, voice, and neglect. Human Relations, 52(7): 895-922.

Vanheule, S., Lievrouw, A. and Verhaeghe, P. 2003. Burnout and intersubjectivity: A psychoanalytical study from a Lacanian perspective. Human Relations, 56(3): 321-338. 
Vantilborgh, T., Bidee, J., Pepermans, R., Willems, J., Huybrechts, G. and Jegers, M. 2012. Volunteers' psychological contracts: Extending traditional views. Nonprofit and Voluntary Sector Quarterly, 41(6): 1072-1091.

Vidaillet, B. and Gamot, G. 2015. Working and resisting when one's workplace is under threat: A Lacanian perspective. Organization Studies, 36(8): 987-1011.

Wolgemuth, J.R. and Donohue, R. 2006. Toward an inquiry of discomfort: Guiding transformation in 'emancipatory' narrative research. Qualitative Inquiry, 12(5): 1022-1039.

Zagenczyk, T. J., Gibney, R., Few, W.T. and Scott, K.L. 2011. Psychological contracts and organizational identification: The mediating effect of perceived organizational support. Journal of Labor Research 32: 254-281. 